Article

\title{
Synthesis of Polythiophene-Fullerene Hybrid Additives as Potential Compatibilizers of BHJ Active Layers
}

\author{
Sofia Kakogianni ${ }^{1}$, Aikaterini K. Andreopoulou ${ }^{1,2, *}$ and Joannis K. Kallitsis ${ }^{1,2}$ \\ 1 Department of Chemistry, University of Patras, University Campus, GR26504 Patras, Greece; \\ skakogianni@upatras.gr (S.K.); j.kallitsis@upatras.gr (J.K.K.) \\ 2 Foundation for Research and Technology Hellas/Institute of Chemical Engineering Sciences \\ (FORTH/ICE-HT), GR26504 Patras, Greece \\ * Correspondence: andreopo@upatras.gr; Tel.: +30-2610-962957
}

Academic Editor: Frank Wiesbrock

Received: 11 November 2016; Accepted: 13 December 2016; Published: 18 December 2016

\begin{abstract}
Perfluorophenyl functionalities have been introduced as side chain substituents onto regioregular poly(3-hexyl thiophene) (rr-P3HT), under various percentages. These functional groups were then converted to azides which were used to create polymeric hybrid materials with fullerene species, either $\mathrm{C}_{60}$ or $\mathrm{C}_{70}$. The P3HT-fullerene hybrids thus formed were thereafter evaluated as potential compatibilizers of $\mathrm{BHJ}$ active layers comprising $\mathrm{P} 3 \mathrm{HT}$ and fullerene based acceptors. Therefore, a systematic investigation of the optical and morphological properties of the purified polymer-fullerene hybrid materials was performed, via different complementary techniques. Additionally, $\mathrm{P} 3 \mathrm{HT}: \mathrm{PC}_{70} \mathrm{BM}$ blends containing various percentages of the herein synthesized hybrid material comprising $r r$-P3HT and $\mathrm{C}_{70}$ were investigated via Transmission Electron Microscopy (TEM) in an effort to understand the effect of the hybrids as additives on the morphology and nanophase separation of this typically used active layer blend for OPVs.
\end{abstract}

Keywords: $r r$-polythiophenes; perfluorophenyl functionalization; fullerene-polymer hybrids; P3HT:PCBM blends; organic photovoltaics (OPVs)

\section{Introduction}

Bulk Heterojunction (BHJ) solar cell devices are widely investigated due to their potential to reach high efficiencies along with their potential of large area coverage and unique flexibility [1-3]. Current state of the art materials that form the bicontinuous interpenetrating network of the active layer are poly(3-hexylthiophene) (P3HT) and [6,6]-phenyl- $\mathrm{C}_{61}$-butyric acid methyl ester (PCBM), providing power conversion efficiencies (PCE) of above $6 \%$, because of their thermal stability [4], high electron mobility $[5,6]$ and especially because it is the current system of choice for printable over large areas organic photovoltaics (OPVs) [7-10]. Among others, decisive parameters that affect the device performance are the materials comprising the active layer, the morphology of the blend as well as the device architecture. In the direction of materials development, new polymeric electron donating materials with complex architectures and lower energy levels [11-15] compared to P3HT, and new electron acceptors based on fullerene [16-18] or even fully organic and polymeric ones [19-21], have been reported. On the other hand, efforts to control the morphology [22,23] of the active blend have been made using thermal annealing or solvent treatment of the blend resulting in significantly higher PCEs [1,4,24-26]. Besides the above-mentioned manipulation of the active layer, another approach that has been followed is the modification of the semiconducting polymer with functional groups that may lead to more complex architectures either co-polymeric or hybrid ones. More specifically, 
co-polymeric materials based on polythiophenes or other conjugated polymers that can interact with or bear fullerene species can provide better miscibility and tune the nanophase separation of the two plain blend components [27-33]. In some cases, the introduction of functional groups like hydroxyl or azide units, as side chain substituents or as end chain groups, not only controls but also stabilizes the morphology of the blended materials [34-38]. Another efficient way to control the morphology is the introduction into the active layer of small quantities of hybrid materials comprising the semiconducting polymer and a carbon nanostructure [39-48]. However, the synthesis of most semiconducting polymeric or copolymeric hybrids involves complicated and multistep synthetic procedures that affect the yield and the cost of the final materials. Moreover, in most such cases, a non-conjugated linkage between the semiconducting polymer and the carbon nanostructure has been employed preventing electronic interactions among the polymeric and fullerene parts of the hybrid materials. To overcome the above bottlenecks, new synthetic strategies involving the "direct" attachment of the two components, organic and fullerene ones, comprising the hybrid materials have been developed [49-54]. Working in this direction, we have recently reported a straightforward methodology for the development of hybrid semiconducting polymeric materials using the electron deficient perfluorophenyl functionality inserted either onto copolymeric materials or as end polymeric chain group [49,54]. Benefits of this methodology are the direct electronic interactions between the two components [50], the absence of extra aliphatic or other non-conjugated parts used as connection bridges which increase the volume of insulating material within the active layer as well as the use of the intermediate perfluorophenyl aromatic azides that are stable over time and ambient storage conditions.

In this present work, we focused on the introduction of perfluorophenyl functionalities as side chain substituents of regioregular-poly(3-hexyl thiophene) ( $r$-P3HT). Several ratios were attempted in order to investigate the influence of the side functionalization onto the properties of $r r$-P3HT. Thereafter, using our previously reported methodology $[49,54]$, the perfluorophenyl functionalities were transformed into azides that performed a [3+2] cycloaddition reaction with $C_{60}$ or $C_{70}$ fullerene species to provide the desired hybrid materials. Extensive purification has been performed in all cases and the purified materials were characterized in respect to their optical and morphological properties. These particular hybrid materials are ideal candidates for the compatibilization and stabilization of P3HT:fullerene active layers used in BHJ polymer photovoltaics, since the introduction of the fullerene species directly along the polythiophene's backbone ensures the hybrids' incorporation in the nanophase created by the neat blend components potentially holding them in close proximity over time and temperature variations during device operation. In order to support the hybrids potentiality as compatibilizers, mixtures of typical P3HT:PC ${ }_{70} \mathrm{BM}$ active $\mathrm{BHJ}$ blends with various percentages of the $C_{70}$ based hybrid material were investigated in respect to the effect of the additive on the morphology of the blend.

\section{Materials and Methods}

\subsection{Materials}

$r r$-P3HT was synthesized according to literature procedure [55]. Fullerene $\mathrm{C}_{60}(99.5 \%)$ was purchased from SES research. Carbon $C_{70}(99.5 \%)$ was kindly provided by Prof. Kyriakos Porfyrakis of the Oxford Carbon Nanomaterials Group, Department of Materials, University of Oxford, UK. Tetrahydrofuran was purchased from Aldrich (Sigma-Aldrich Chemie GmbH, Taufkirchen, Germany) and was distilled with benzophenone and metallic sodium $\left(\mathrm{THF}_{\mathrm{dry}}\right)$. All the other solvents and reagents were purchased from Aldrich and used without further purification unless otherwise stated.

\subsection{Instrumentation}

${ }^{1} \mathrm{H},{ }^{19} \mathrm{~F},{ }^{15} \mathrm{~N}$ Nuclear Magnetic Resonance (NMR) spectra were recorded on a Bruker Advance (Bruker BioSpin GmbH, Magnet Division, Karlsruhe, Germany) DPX 400.13, 376.5 and $40.55 \mathrm{MHz}$ spectrometer, respectively, in $\mathrm{CDCl}_{3}$ containing TMS as internal standard. 
Gel permeation chromatography (GPC) measurements were carried out using a Polymer Lab chromatographer (Agilent Technologies, Santa Clara, CA, USA) equipped with two PLgel $5 \mu \mathrm{m}$ mixed columns and a UV detector, using $\mathrm{CHCl}_{3}$ as eluent with a flow rate of $1 \mathrm{~mL} / \mathrm{min}$ at $25^{\circ} \mathrm{C}$, calibrated versus polystyrene standards.

Attenuated Total Reflectance (ATR) spectra were recorded on a “Bruker Optics' Alpha-P Diamond ATR Spectrometer of Bruker Optics GmbH" (Ettlingen, Germany).

Thermogravimetric analysis (TGA) was carried out on $\sim 8 \mathrm{mg}$ samples contained in alumina crucibles in a Labsys TM TG apparatus of Setaram (Caluire, France) under nitrogen and at a heating rate of $10^{\circ} \mathrm{C} / \mathrm{min}$.

UV-Vis spectra were recorded using a Hitachi U-1800 spectrophotometer (Hitachi High-Technologies Europe $\mathrm{GmbH}$, Mannheim, Germany) Continuous wave photoluminescence was measured on a Perkin Elmer LS50B spectrofluorometer (Waltham, MA, USA). All UV-Vis and PL measurements were performed in air using quartz cuvettes and flat substrates for the examination of solutions and films, respectively.

The Blend Preparation involved the mixing of stock solutions of P3HT $\left(10 \mathrm{mg} \cdot \mathrm{mL}^{-1}\right)$ and $\mathrm{PC}_{70} \mathrm{BM}\left(10 \mathrm{mg} \cdot \mathrm{mL}^{-1}\right)$ to prepare the P3HT:PC 70 BM 1:1 w/w. Afterwards, 0.125 and $0.625 \mathrm{~mL}$ of the $\left[\right.$ P3HT $\left.0.6-(\text { P3HT-5F })_{0.3}-(\text { P3HT-5F-N-C } 70)_{0.1}\right]\left(8 \mathrm{mg} \cdot \mathrm{mL}^{-1}\right)$ were added to prepare the $20 \%$ and the $50 \%$ blends with the hybrid polymer, respectively.

Transmission electron microscopy (TEM) measurements were performed on a JEOL JEM2100 (Peabody, MA, USA) operating at $200 \mathrm{kV}$. Sample preparation for TEM examination of the $\mathrm{PP} \mathrm{HT}_{0.6^{-}}$ (P3HT-5F $)_{0.4}$, [P3HT $\left.0.6^{-}(\mathrm{P} 3 \mathrm{HT}-5 \mathrm{~F})_{0.2}-\left(\mathrm{P} 3 \mathrm{HT}-5 \mathrm{~F}-\mathrm{N}-\mathrm{C}_{60}\right)_{0.2}\right],\left[\mathrm{P}_{3} \mathrm{HT}_{0.6}-(\mathrm{P} 3 \mathrm{HT}-5 \mathrm{~F})_{0.3}-\left(\mathrm{P} 3 \mathrm{HT}-5 \mathrm{~F}-\mathrm{N}-\mathrm{C}_{70}\right)_{0.1}\right]$ involved the preparation of dilute solutions of the samples in $o-\mathrm{DCB}$ and filtration through a $0.45 \mu \mathrm{m}$ filter. For the hybrids a drop of the solution was placed on $3 \mathrm{~mm}$ carbon coated copper grids (Electron Microscopy Sciences) and the samples were dried in air for 2 days. For the blends examination via TEM, a drop of the blends solution was placed on $3 \mathrm{~mm}$ carbon coated copper grids (Electron Microscopy Sciences) and after $30 \mathrm{~s}$ the solvent was removed with filter paper.

\subsection{Synthetic Procedures}

\subsubsection{Side $\left[\mathrm{P} 3 \mathrm{HT}_{0.6}-(\mathrm{P} 3 \mathrm{HT}-\mathrm{Br})_{0.4}\right][56]$}

A $50 \mathrm{~mL}$ round bottom flask, equipped with a reflux condenser and a magnetic stirrer, was flamed under vacuum degassed and filled with argon. P3HT (500 mg, $3 \mathrm{mmol}$ ) was added and dissolved in $30 \mathrm{~mL} \mathrm{CHCl}$ and the system was degassed and flushed with argon again. The flask was covered with aluminum foil and NBS (214 mg, $1.2 \mathrm{mmol})$ was added in three portions. The mixture was stirred for $22 \mathrm{~h}$ at room temperature. Then, $15 \mathrm{~mL} \mathrm{Na}_{2} \mathrm{SO}_{3} 5 \%$ aqueous solution were added to the system and the mixture was extracted with $\mathrm{CHCl}_{3}$ and deionized water. The organic phase was dried with anhydrous $\mathrm{MgSO}_{4}$, filtrated and rotary evaporated. The obtained solid was dried under vacuum at $40{ }^{\circ} \mathrm{C}$. Bromination ratio calculated from ${ }^{1} \mathrm{H}$ NMR: $40 \%$, yield: $92 \%{ }^{1} \mathrm{H} \mathrm{NMR}\left(\delta_{\mathrm{H}} ; \mathrm{CDCl} 3\right.$; $\mathrm{Me}_{4} \mathrm{Si}$ ): 7.00 (broad, $\left.1 \mathrm{H}\right), 2.80($ broad, $2 \mathrm{H}), 2.64$ (broad, $2 \mathrm{H}-\mathrm{Br}$ substituted thiophene), 1.65(broad, $4 \mathrm{H}$ ), 1.53-1.22(broad, $12 \mathrm{H}$ ), 0.88(broad, $6 \mathrm{H}$ ).

The same procedure was used for all other ratios.

\subsubsection{Side $\left[\mathrm{P}^{3} \mathrm{HT}_{0.6}-(\mathrm{P} 3 \mathrm{HT}-5 \mathrm{~F})_{0.4}\right]$}

A $100 \mathrm{~mL}$ round bottom flask, equipped with a reflux condenser and a magnetic stirrer, was degassed (flamed under vacuum) and filled with argon. Side $\left[\mathrm{P}_{3} \mathrm{HT}_{0.6}-(\mathrm{P} 3 \mathrm{HT}-\mathrm{Br})_{0.4}\right](400 \mathrm{mg}$, $0.81 \mathrm{mmol})$, pentafluorophenyl boronic acid $(205 \mathrm{mg}, 1 \mathrm{mmol})$ and $\mathrm{Pd}\left(\mathrm{PPh}_{3}\right)_{4}(30 \mathrm{mg}, 0.02 \mathrm{mmol})$ were dissolved in $20 \mathrm{~mL}$ toluene and then $\mathrm{Na}_{2} \mathrm{CO}_{3}(1.20 \mathrm{~mL}, 2.42 \mathrm{mmol})$ in $2 \mathrm{M}$ aqueous were added. The mixture was degassed and flushed with argon again and refluxed for $72 \mathrm{~h}$. Then, the mixture was filtered in order to remove the catalyst and the solvent was rotary evaporated. The obtained solid was washed several times with $\mathrm{MeOH}$ and deionized water. The final solid was dried under 
vacuum at $50{ }^{\circ} \mathrm{C}$. Yield: $99 \%{ }^{1} \mathrm{H}$ NMR $\left(\delta_{\mathrm{H}} ; \mathrm{CDCl} 3\right.$; Me4Si): 7.00 (broad, $\left.1 \mathrm{H}\right), 2.80$ (broad, $\left.2 \mathrm{H}\right), 2.64$ (broad, $2 \mathrm{H}), 1.65$ (broad, $4 \mathrm{H}), 1.53-1.22$ (broad, $12 \mathrm{H}), 0.88$ (broad, $6 \mathrm{H}),{ }^{19} \mathrm{~F} \mathrm{NMR}\left(\delta_{\mathrm{F}} ; \mathrm{CDCl} 3\right.$; Me4Si): -139.10, $-150.91,-159.94$.

\subsubsection{Side $\left[\mathrm{P} 3 \mathrm{HT}_{0.6}-(\mathrm{P} 3 \mathrm{HT}-5 \mathrm{~F})_{0.2}-\left(\mathrm{P} 3 \mathrm{HT}-5 \mathrm{~F}-\mathrm{N}_{3}\right)_{0.2}\right]$}

A $50 \mathrm{~mL}$ round bottom flask with a reflux condenser and a magnetic stirrer was degassed and filled with argon. Side $\left[\right.$ P3HT $\left.{ }_{0.6}-(\mathrm{P} 3 \mathrm{HT}-5 \mathrm{~F})_{0.4}\right](400 \mathrm{mg}, 1.72 \mathrm{mmol})$ was dissolved in $35 \mathrm{~mL}$ THF (dry) and $\mathrm{NaN}_{3}(22 \mathrm{mg}, 0.34 \mathrm{mmol})$ was added. The mixture was degassed and flushed with argon again and heated at $40{ }^{\circ} \mathrm{C}$ for $48 \mathrm{~h}$. The reaction mixture was then precipitated into a mixture of deionized water:methanol (1:1). The desired azide was obtained after filtration and the solid dried under vacuum at $30{ }^{\circ} \mathrm{C}$ for $24 \mathrm{~h}$. Yield: $96 \%{ }^{1} \mathrm{H}$ NMR $\left(\delta_{\mathrm{H}} ; \mathrm{CDCl} 3\right.$; Me $4 \mathrm{Si}$ ): 7.00(broad, $\left.1 \mathrm{H}\right), 2.80$ (broad, $2 \mathrm{H}$ ), 2.64(broad, $2 \mathrm{H}), 1.65$ (broad, $4 \mathrm{H}), 1.53-1.22$ (broad, $12 \mathrm{H}), 0.88$ (broad, $6 \mathrm{H}),{ }^{19} \mathrm{~F}$ NMR $\left(\delta_{\mathrm{F}} ; \mathrm{CDCl} 3\right.$; Me4Si): -135.76 , $-136.36,{ }^{15} \mathrm{~N}$ NMR $\left(\delta_{\mathrm{N}} ; \mathrm{CDCl} 3 ; \mathrm{Me} 4 \mathrm{Si}\right): 233.84,51.73$.

The same procedure was used for the side $\left[\mathrm{P}_{3} \mathrm{HT}_{0.6}-(\mathrm{P} 3 \mathrm{HT}-5 \mathrm{~F})_{0.3}-\left(\mathrm{P} 3 \mathrm{HT}-5 \mathrm{~F}-\mathrm{N}_{3}\right)_{0.1}\right]$.

\subsubsection{Side $\left[\mathrm{P} \mathrm{HT}_{0.6}-(\mathrm{P} 3 \mathrm{HT}-5 \mathrm{~F})_{0.2}-\left(\mathrm{P} 3 \mathrm{HT}-5 \mathrm{~F}-\mathrm{N}-\mathrm{C}_{60}\right)_{0.2}\right]$}

A $50 \mathrm{~mL}$ round bottom flask, equipped with a reflux condenser and a magnetic stirrer, was degassed (flamed under vacuum) and filled with argon. Side [P3HT $\left.\mathrm{P}_{0.6}-\left(\mathrm{P} 3 \mathrm{HT}-5 \mathrm{~F}-\mathrm{N}_{3}\right)_{0.4}\right](150 \mathrm{mg}), \mathrm{C}_{60}$ $(87 \mathrm{mg}, 0.12 \mathrm{mmol}$ ) and $60 \mathrm{~mL} o$-DCB were added and the system was degassed and flushed with argon again. The reaction mixture was stirred at $140{ }^{\circ} \mathrm{C}$ for $72 \mathrm{~h}$. After evaporation of the solvent, the solid was stirred in toluene for $72 \mathrm{~h}$ in order to remove the unreacted $\mathrm{C}_{60}$. The mixture was filtrated and the solid was evaluated via Thin Layer Chromatography (TLC), using toluene as the mobile phase on silica gel plates, and ATR for traces of unreacted $C_{60}$ and if necessary the solid was again stirred in toluene. The final purified hybrid material was dried under vacuum at $50^{\circ} \mathrm{C}$ overnight affording $100.00 \mathrm{mg}$ of the hybrid $\mathrm{C}_{60}$ based polymer.

\subsubsection{Side $\left[\mathrm{P} 3 \mathrm{HT}_{0.6}-(\mathrm{P} 3 \mathrm{HT}-5 \mathrm{~F})_{0.3}-\left(\mathrm{P} 3 \mathrm{HT}-5 \mathrm{~F}-\mathrm{N}-\mathrm{C}_{70}\right)_{0.1}\right]$}

A $50 \mathrm{~mL}$ round bottom flask, equipped with a reflux condenser and a magnetic stirrer, was degassed (flamed under vacuum) and filled with argon. Side $\left[\mathrm{P}_{3} \mathrm{HT}_{0.6}-\left(\mathrm{P} 3 \mathrm{HT}-5 \mathrm{~F}-\mathrm{N}_{3}\right)_{0.4}\right](150 \mathrm{mg}), \mathrm{C}_{70}$ $(61 \mathrm{mg}, 0.093 \mathrm{mmol})$ and $50 \mathrm{~mL} o-\mathrm{DCB}$ were added and the system was degassed and flushed with argon again. The reaction mixture was stirred at $140{ }^{\circ} \mathrm{C}$ for $72 \mathrm{~h}$. After evaporation of the solvent, the solid was stirred in toluene for $72 \mathrm{~h}$ in order to remove the unreacted $\mathrm{C}_{70}$. The mixture was filtrated and the solid was evaluated via TLC, using toluene as the mobile phase on silica gel plates, and ATR for traces of unreacted $C_{70}$ in which case the solid was again stirred in toluene. The final purified material was dried under vacuum at $50{ }^{\circ} \mathrm{C}$ overnight affording $115.00 \mathrm{mg}$ of the hybrid $\mathrm{C}_{70}$ based polymer.

\section{Results and Discussion}

\subsection{Synthesis of Side-Br P3HTs}

Typical GRIM polymerization conditions of 2,5-dibromo-3-hexyl-thiophene in freshly distilled THF using $\mathrm{MeMgCl}$ as the Grignard reagent and $\mathrm{NiCl}_{2}$ (dppp) as catalyst were used to prepare the initial $r r$-P3HT [55]. The crude polymer was obtained after precipitation in methanol and was further purified via Soxhlet extractions using methanol, $n$-hexane and chloroform as fractionation solvents. For this work, we used only the chloroform fraction of the $r r$-P3HT with a corresponding $\mathrm{Mn}=28,500, \mathrm{PDI}=1.2$. For the side functionalization of $r r$-P3HT, bromination at the 4-position of the thiophene ring was performed [41,56-59] (Scheme 1). Various equivalents of the brominating reagent, $\mathrm{N}$-Bromosuccinimide (NBS), in respect to the thiophene repeating units were used to achieve different bromination degrees of the polymeric backbone. The rate of bromine-functionalization is calculated from the ${ }^{1} \mathrm{H}$ NMR of the side-[P3HT-(P3HT-Br)] (Figure 1). The appearance of a broadened bimodal peak at $\sim 7-7.2 \mathrm{ppm}$ and of two peaks at $\sim 2.8-2.6 \mathrm{ppm}$ is attributed to the successful bromination of 
the thiophene ring at 4-position and also the partial disruption of the regioregularity of the P3HT's backbone. More specifically, the insertion of the bromine atom at the 4-position of the thiophene ring causes the stepwise reduction of the aromatic hydrogens of P3HT initially located at $\sim 7 \mathrm{ppm}$ and a stepwise shift of the $\alpha$-methylene hydrogen peak of the hexyl group from 2.8 to $\sim 2.6 \mathrm{ppm}$. The initial $r r$-P3HT shows a peak at $2.8 \mathrm{ppm}$ corresponding to the $\alpha$-methylene protons of the hexyl aliphatic chains at the 3-position of the thiophene ring connected in a head-to-tail mode. After bromination at the 4-position of the thiophene ring, via electrophilic substitution affording the side-[P3HT-(P3HT-Br)] polymers (Scheme 1), a new broad proton signal at about $2.6 \mathrm{ppm}$ appears attributed to the $\alpha$-methylene protons of those hexyl chains attached to the partially brominated thienyl ring. This chemical shift is down-field shifted compared to that of their initial counterparts, indicating the influence of the bromine as an electron-attracting group on the $\alpha$-methylene protons. From the integral ratio of the peaks at $2.8-2.6 \mathrm{ppm}$ to the one at $\sim 7 \mathrm{ppm}$, the bromine substitution ratio in the side-[P3HT-(P3HT-Br)] polymers is calculated. In the ATR spectra (Figure 2), it is observed that as the ratio of the bromine-functionalization increases the characteristic peaks of the $r r$-P3HT are broadened, compared to the unfunctionalized $r r$-P3HT. The appearance of two new peaks at $\sim 1600$ and $\sim 1720 \mathrm{~cm}^{-1}$, respectively, is attributed to the successful bromination of the thiophene ring at the 4-position [41].

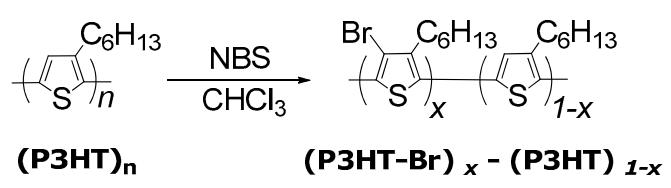

Scheme 1. Synthetic procedure of side functionalization of $r r$-P3HT.

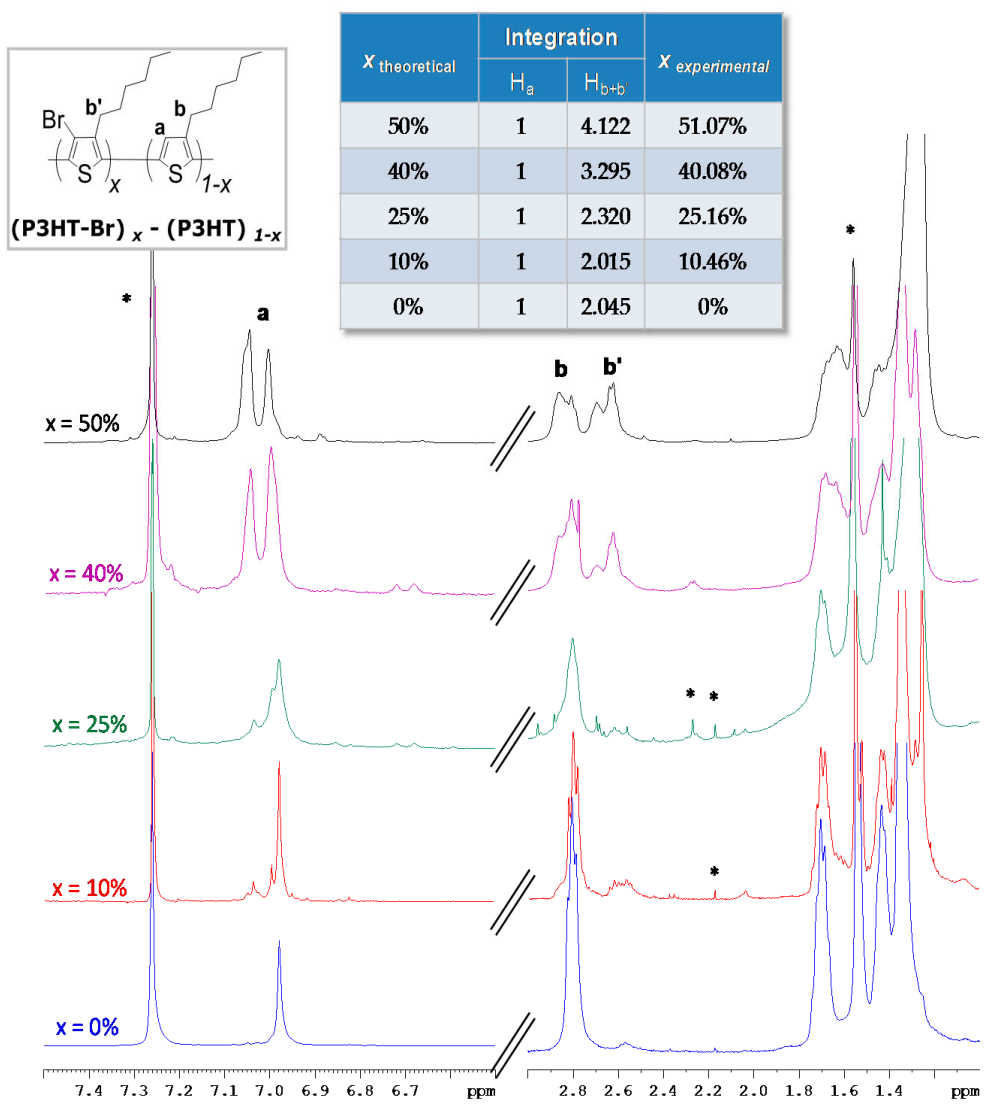

Figure 1. ${ }^{1} \mathrm{H}$ NMR spectra of the various side bromine functionalized $\mathrm{P} 3 \mathrm{HTs}$, in $\mathrm{CDCl}_{3}$ (the asterisks indicate solvent traces). 


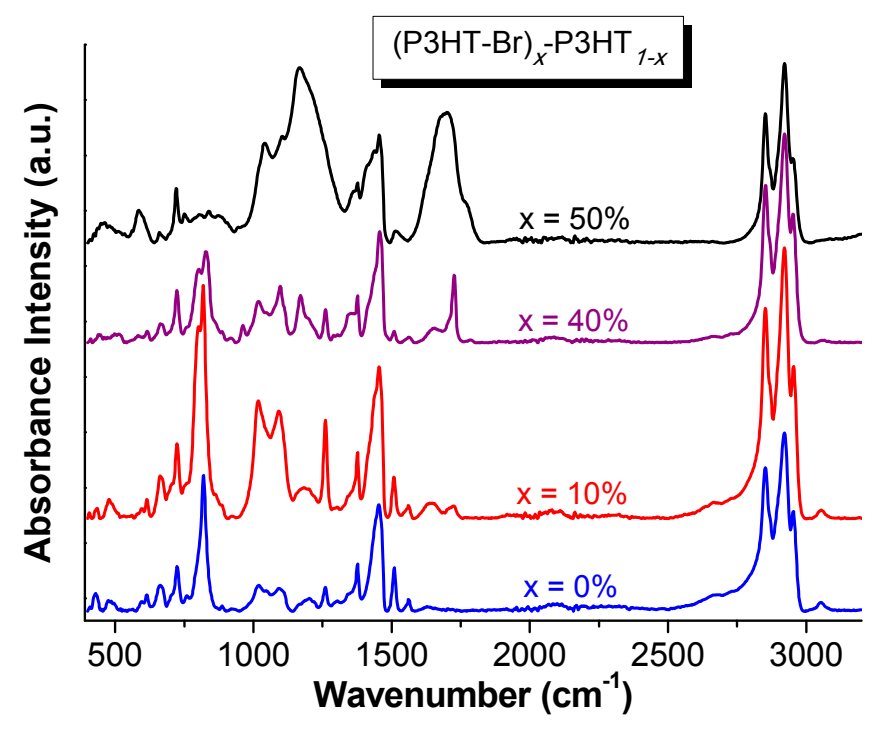

Figure 2. ATR spectra of an unfunctionalized P3HT and various ratios of side bromine-functionalized P3HTs.

As it is known from previous literature findings on the side functionalization of $r r$-P3HT [41,56-59], high levels of functionalization at the 4-position of the thiophene ring affect the planarity along the polymer's backbone and also disrupt the effective conjugation length of P3HT. Additionally, high functionalization degrees with fullerene species along the rr-P3HT backbone, which is our herein ultimate target, were inevitably going to provide hybrid materials with poor solubility in common organic solvents. Thus, and in order to prepare processable hybrid materials, but with adequate functionalization levels and with efficient number of side-fullerene units to act as compatibilizers of the neat components' blends, we chose the $40 \%$ side bromine-functionalized P3HT for further studies. Therefore, the side $r r-\left[\mathrm{P}_{3} \mathrm{HT}_{0.6}-(\mathrm{P} 3 \mathrm{HT}-\mathrm{Br})_{0.4}\right]$ reacted with an equivalent amount of perfluorophenyl boronic acid under Suzuki cross coupling conditions to form the respective side $\left[\mathrm{P}_{3} \mathrm{HT}_{0.6}-(\mathrm{P} 3 \mathrm{HT}-5 \mathrm{~F})_{0.4}\right]$ polymer (Scheme 2). The successful introduction of the perfluorophenyl ring at the side position of the P3HT's polymeric backbone was proven through ${ }^{19} \mathrm{~F}$ NMR spectroscopy (Figure 3). The ${ }^{19} \mathrm{~F}$ NMR spectrum presents three peaks attributed to the three fluorine species of the perfluorinated ring. Afterwards, the perfluorophenyl groups of the $\mathrm{P}_{3} \mathrm{HT}_{0.6}-(\mathrm{P} 3 \mathrm{HT}-5 \mathrm{~F})_{0.4}$ polymer were transformed into azides using sodium azide in THF [38]. Various azidation degrees were employed affording materials with $40 \%, 20 \%$ or $10 \%$ overall theoretical azidation degrees (Scheme 2, Table 1) in order to be able thereafter to incorporate different amounts of fullerenes and eventually produce processable hybrid polymers with $\mathrm{C}_{60}$ or $\mathrm{C}_{70}$. The successful azidation was confirmed using ATR and ${ }^{15} \mathrm{~N} N M R$ spectroscopies. The ATR spectrum of the $20 \%$ side perfluorophenyl azide showed a low intensity peak at $2064 \mathrm{~cm}^{-1}$ which demonstrates the azide formation (Figure 4), while for the $10 \%$ azide functionalized polymer the azide peak was not clearly observed due to the low ratio of the azide functionality over the total polymer. On the other hand, ${ }^{15}$ N NMR spectroscopy, as shown in Figure 5, revealed two clear peaks owing to the two nitrogen species of the azide functionality even for the $10 \%$ azide functionalized polymer.

Table 1. Azidation ratios of $\left[\mathrm{P}_{3} \mathrm{HT}_{0.6}-(\mathrm{P} 3 \mathrm{HT}-5 \mathrm{~F})_{0.4}\right]$ and the respective abbreviations of the functionalized polymers obtained.

\begin{tabular}{cc}
\hline $\begin{array}{c}\text { Azide Functionalization Degree of } \\
\left(\mathbf{P} 3 \mathrm{HT}-5 \mathrm{~F}-\mathbf{N}_{\mathbf{3}}\right)_{\boldsymbol{a x}} \mathbf{-}(\mathbf{P} 3 \mathrm{HT}-5 \mathrm{~F})_{\boldsymbol{x}} \mathbf{-}(\mathbf{P} 3 \mathrm{HT})_{\mathbf{1}-\boldsymbol{x}}\end{array}$ & Side azide \\
\hline 1 & {$\left[\mathrm{P}_{3} \mathrm{HT}_{0.6}-\left(\mathrm{P} 3 \mathrm{HT}-5 \mathrm{~F}-\mathrm{N}_{3}\right)_{0.4}\right]$} \\
0.5 & {$\left[\mathrm{P}_{\mathrm{H}} \mathrm{HT}_{0.6}-(\mathrm{P} 3 \mathrm{HT}-5 \mathrm{~F})_{0.2}-\left(\mathrm{P} 3 \mathrm{HT}-5 \mathrm{~F}-\mathrm{N}_{3}\right)_{0.2}\right]$} \\
0.25 & {$\left[\mathrm{P} 3 \mathrm{HT}_{0.6}-(\mathrm{P} 3 \mathrm{HT}-5 \mathrm{~F})_{0.3}-\left(\mathrm{P} 3 \mathrm{HT}-5 \mathrm{~F}-\mathrm{N}_{3}\right)_{0.1}\right]$} \\
\hline
\end{tabular}




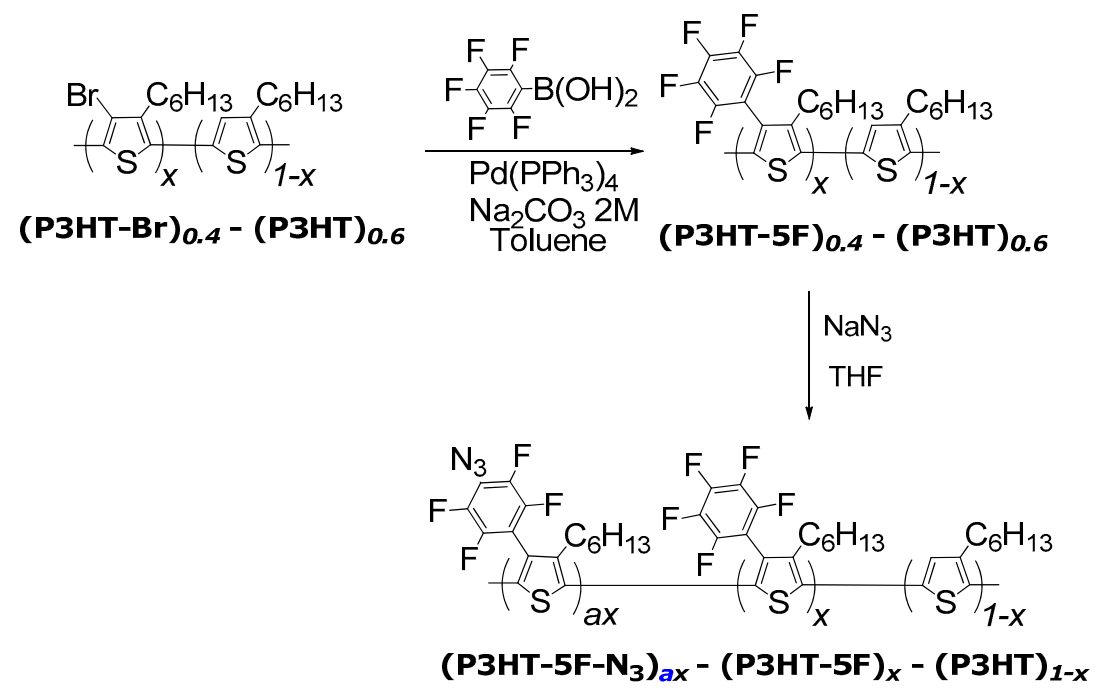

Scheme 2. Synthetic procedure of side perfluorophenyl P3HT and their azide transformation; $a$ indicates the azide functionalization degree.

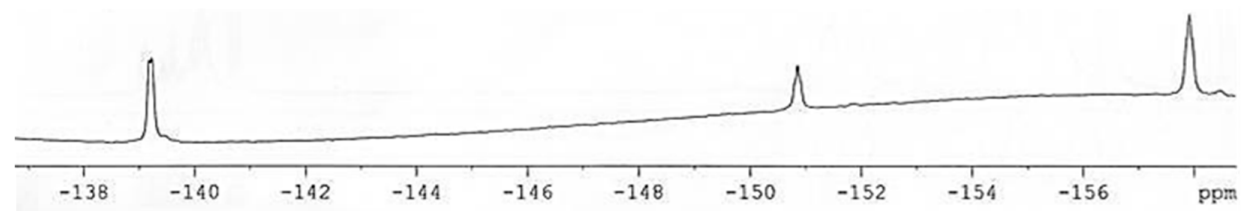

Figure 3. ${ }^{19} \mathrm{~F}$ NMR spectra (in $\left.\mathrm{CDCl}_{3}\right)$ of the $\mathrm{P}_{3} \mathrm{HT}_{0.6}-(\mathrm{P} 3 \mathrm{HT}-5 \mathrm{~F})_{0.4}$.

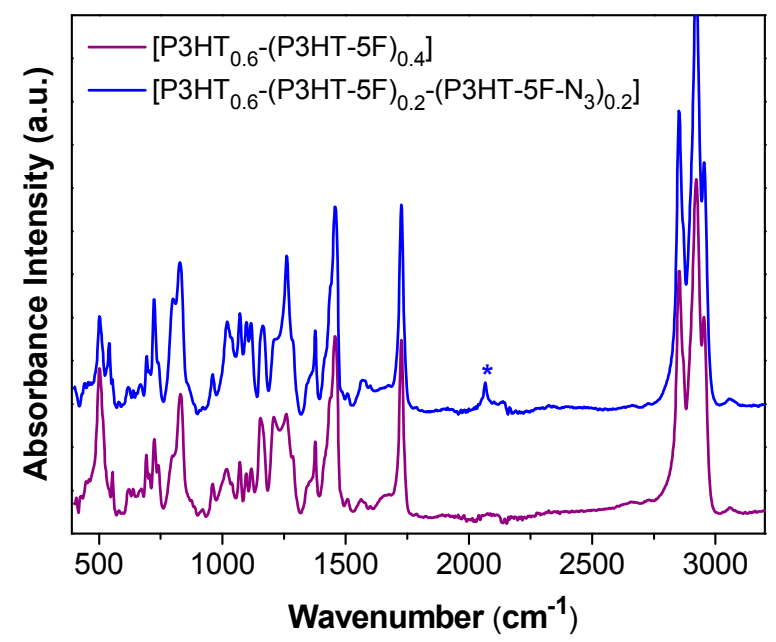

Figure 4. ATR spectra of the $\left[\mathrm{P} 3 \mathrm{HT}_{0.6}-(\mathrm{P} 3 \mathrm{HT}-5 \mathrm{~F})_{0.4}\right]$ and azide $\left[\mathrm{P}_{3} \mathrm{HT}_{0.6}-(\mathrm{P} 3 \mathrm{HT}-5 \mathrm{~F})_{0.2}-\left(\mathrm{P} 3 \mathrm{HT}-5 \mathrm{~F}-\mathrm{N}_{3}\right)_{0.2}\right]$ (the asterisk indicates the azide functionality).

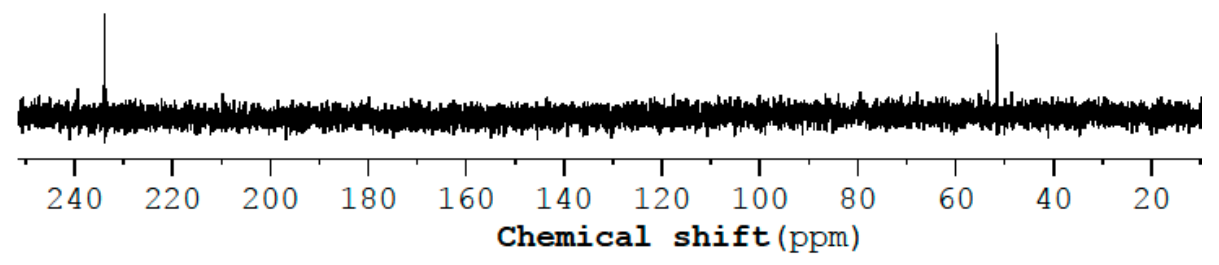

Figure $5 .{ }^{15} \mathrm{~N}$ NMR spectra of the side $\left.\left[\mathrm{P}_{3} \mathrm{HT}_{0.6}-(\mathrm{P} 3 \mathrm{HT}-5 \mathrm{~F})_{0.3}-\mathrm{P} 3 \mathrm{HT}-5 \mathrm{~F}-\mathrm{N}_{3}\right)_{0.1}\right]$, in $\mathrm{CDCl}_{3}$. 


\subsection{Synthesis of Side-P3HT-(P3HT-5F) Hybrids}

The side P3HT-perfluorophenyl azides have been used to prepare side hybrid semiconducting polymers with either $\mathrm{C}_{60}$ or $\mathrm{C}_{70}$ fullerenes. When the side $\left[\mathrm{P}_{3} \mathrm{HT}_{0.6}-\left(\mathrm{P} 3 \mathrm{HT}-5 \mathrm{~F}-\mathrm{N}_{3}\right)_{0.4}\right]$ reacted with an equivalent amount of $\mathrm{C}_{60}$ to the azide content, the final hybrid polymer was insoluble in common organic solvents. In order to avoid such insolubility problems, the side $\left[\mathrm{P}_{3} \mathrm{HT}_{0.6}-(\mathrm{P} 3 \mathrm{HT}-5 \mathrm{~F})_{0.2}-\left(\mathrm{P} 3 \mathrm{HT}-5 \mathrm{~F}-\mathrm{N}_{3}\right)_{0.2}\right]$ reacted with $\mathrm{C}_{60}$ fullerene while the side $\left[\mathrm{P}_{3} \mathrm{HT}_{0.6}-(\mathrm{P} 3 \mathrm{HT}-5 \mathrm{~F})_{0.3}-\left(\mathrm{P} 3 \mathrm{HT}-5 \mathrm{~F}-\mathrm{N}_{3}\right)_{0.1}\right.$ ] reacted with $\mathrm{C}_{70}$ providing the desired hybrid semiconducting polymers (Scheme 3 ) and leading to processable hybrid materials. After the [3+2] cycloaddition reaction, the side [P3HT-(P3HT-5F)]-hybrids with fullerenes were thoroughly washed several times with toluene to remove any unreacted fullerene species. A thorough ATR examination was performed for both hybrid materials after each subsequent washing step. When no further reduction of the fullerene peaks was noticed, we concluded that all unreacted traces of $\mathrm{C}_{60}$ or $\mathrm{C}_{70}$ were successfully removed (Figure 6).

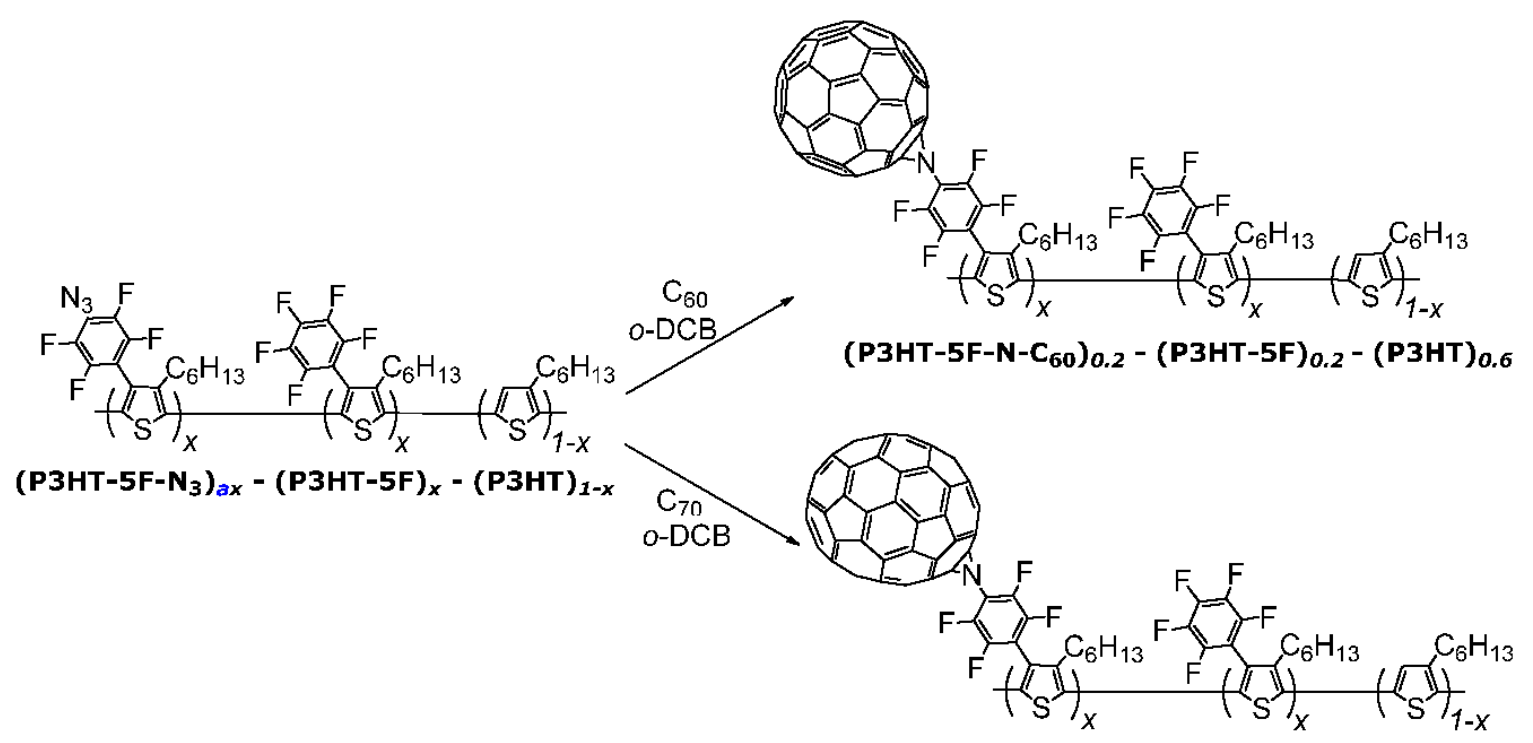

Scheme 3. Synthetic procedure of side- $\left[\mathrm{P}_{3} \mathrm{HT}_{0.6}-(\mathrm{P} 3 \mathrm{HT}-5 \mathrm{~F})_{0.4}\right]$ hybrids with $\mathrm{C}_{60}$ or $\mathrm{C}_{70}$ fullerenes.
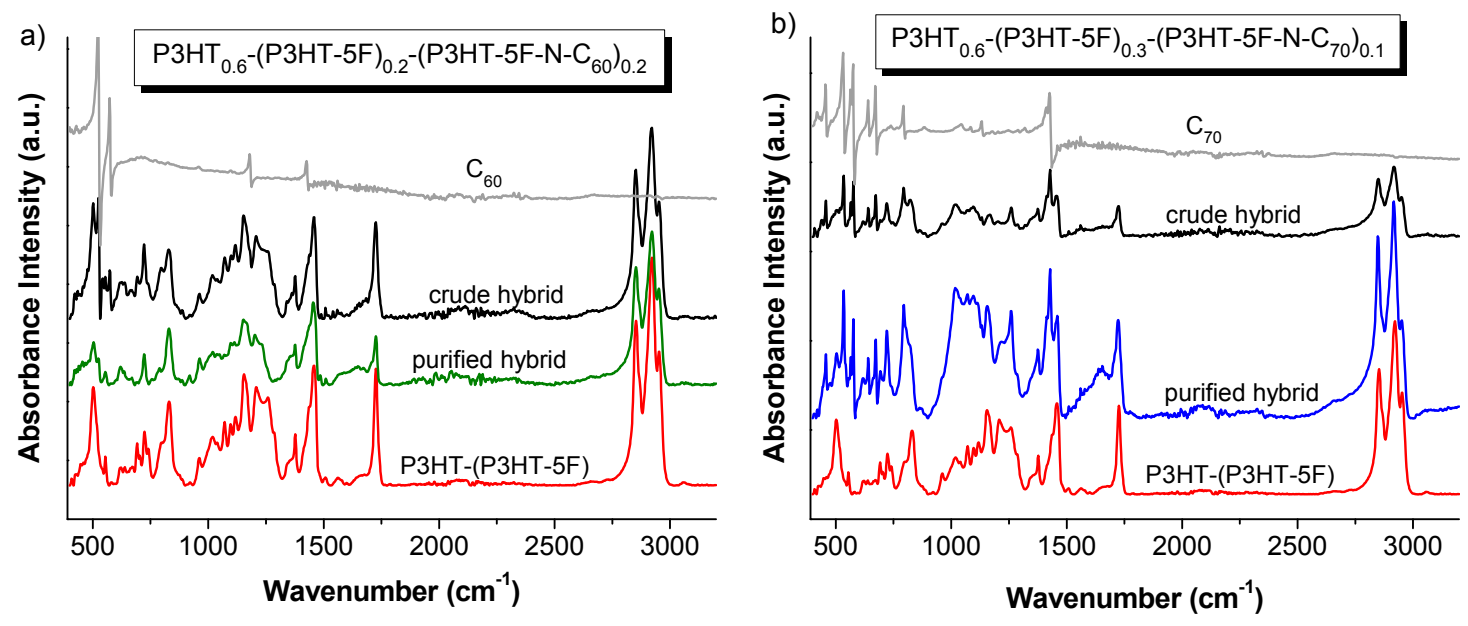

Figure 6. ATR spectra of: (a) $\mathrm{C}_{60}$; and (b) $\mathrm{C}_{70}$ based side $\left[\left(\mathrm{P}_{3} \mathrm{HT}_{0.6}-\mathrm{P} 3 \mathrm{HT}-5 \mathrm{~F}\right)_{0.4}\right]$ hybrids, in comparison with the initial P3HT-(P3HT-5F) and the plain fullerenes, respectively.

Thermogravimetric analysis (TGA) of the side-functionalized $\left[\mathrm{P} 3 \mathrm{HT}_{0.6}-(\mathrm{P} 3 \mathrm{HT}-5 \mathrm{~F})_{0.4}\right]$ and the hybrid with fullerene $\mathrm{C}_{70}$ (Figure 7) revealed at $800{ }^{\circ} \mathrm{C}$ a $44 \%$ residue for the $\left[\mathrm{P}_{3} \mathrm{HT}_{0.6}-(\mathrm{P} 3 \mathrm{HT}-5 \mathrm{~F})_{0.4}\right]$ 
and a $62 \%$ residue for the $\left[\mathrm{P}_{3} \mathrm{HT}_{0.6}-(\mathrm{P} 3 \mathrm{HT}-5 \mathrm{~F})_{0.3}-\left(\mathrm{P} 3 \mathrm{HT}-5 \mathrm{~F}-\mathrm{N}-\mathrm{C}_{70}\right)_{0.1}\right]$ hybrid, respectively. As expected, the hybrid polymer presented a higher residue due to the incorporation of the fullerene species.

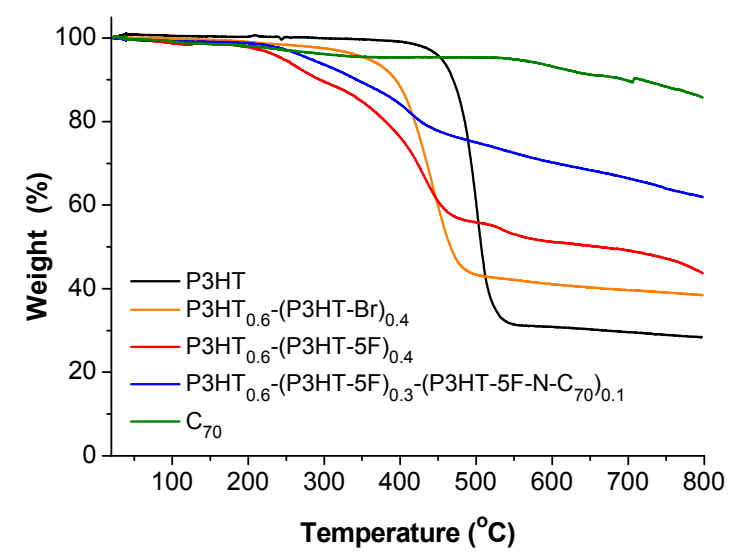

Figure 7. TGA thermograms of $r r-\mathrm{P} 3 \mathrm{HT}, \quad\left[\mathrm{P} 3 \mathrm{HT}_{0.6}-(\mathrm{P} 3 \mathrm{HT}-\mathrm{Br})_{0.4}\right], \quad\left[\mathrm{P}_{3} \mathrm{HT}_{0.6}-(\mathrm{P} 3 \mathrm{HT}-5 \mathrm{~F})_{0.4}\right]$, $\left[\mathrm{P} \mathrm{HT}_{0.6}-(\mathrm{P} 3 \mathrm{HT}-5 \mathrm{~F})_{0.3}-\left(\mathrm{P} 3 \mathrm{HT}-5 \mathrm{~F}-\mathrm{N}-\mathrm{C}_{70}\right)_{0.1}\right]$ and $\mathrm{C}_{70}$ fullerene.

\subsection{Optical Properties}

The optical properties of the synthesized hybrid materials compared to the initial side $\left[\mathrm{P}_{3} \mathrm{HT}_{0.6}-(\mathrm{P} 3 \mathrm{HT}-5 \mathrm{~F})_{0.4}\right]$ were investigated both in $o-\mathrm{DCB}$ solutions and in film form. The UV-Vis spectra of the initial side- $\left[\mathrm{P}_{3} \mathrm{HT}_{0.6}-(\mathrm{P} 3 \mathrm{HT}-5 \mathrm{~F})_{0.4}\right]$ both in $o-\mathrm{DCB}$ solution (Figure $8 \mathrm{a}$ ) and in film form (Figure 8a) presented a blue shift compared to the unfunctionalized $r r$-P3HT. This phenomenon is attributed to the perturbation of the regioregularity of the $\mathrm{P} 3 \mathrm{HT}$ backbone after the functionalization at the 4-position of the thiophene unit. The hybrid material $\left[\mathrm{P}_{3} \mathrm{HT}_{0.6}-(\mathrm{P} 3 \mathrm{HT}-5 \mathrm{~F})_{0.2}-\left(\mathrm{P} 3 \mathrm{HT}-5 \mathrm{~F}-\mathrm{N}-\mathrm{C}_{60}\right)_{0.2}\right]$ presented an even greater blue-shift compared to its functionalized $\mathrm{P} 3 \mathrm{HT}$ precursor, while the characteristic absorbance bands of the fullerene $C_{60}$ were observed in solution as a shoulder at $\sim 330 \mathrm{~nm}$ whereas, in film form, the absorption peak up to $\sim 300 \mathrm{~nm}$ peak is attributed to the fullerenic part of the hybrid. On the other hand, the hybrid material [P3HT $\left.{ }_{0.6}-(\mathrm{P} 3 \mathrm{HT}-5 \mathrm{~F})_{0.3}-\left(\mathrm{P} 3 \mathrm{HT}-5 \mathrm{~F}-\mathrm{N}-\mathrm{C}_{70}\right)_{0.1}\right]$ clearly presented the characteristic absorbance bands of $C_{70}$ fullerene both in solutions and in film form in the region 300-400 nm.
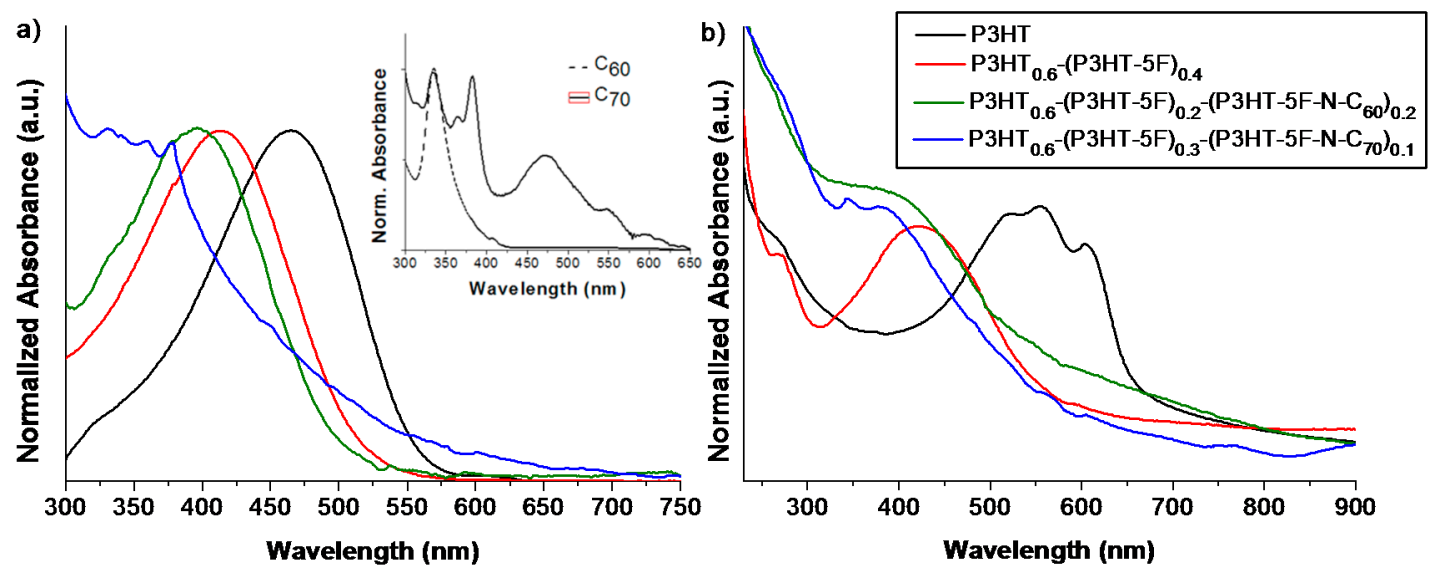

Figure 8. Normalized Absorption spectra in: (a) $o$-DCB solutions; and (b) film form of un functionalized P3HT, side functionalized [P3HT $\left.\mathrm{P}_{0.6}-(\mathrm{P} 3 \mathrm{HT}-\mathrm{Br})_{0.4}\right],\left[\mathrm{P}_{3} \mathrm{HT}_{0.6}-(\mathrm{P} 3 \mathrm{HT}-5 \mathrm{~F})_{0.4}\right]$, $\left[\mathrm{P}_{3} \mathrm{HT}_{0.6}-(\mathrm{P} 3 \mathrm{HT}-5 \mathrm{~F})_{0.2}-\left(\mathrm{P} 3 \mathrm{HT}-5 \mathrm{~F}-\mathrm{N}-\mathrm{C}_{60}\right)_{0.2}\right]$ and $\left[\mathrm{P} 3 \mathrm{HT}_{0.6}-(\mathrm{P} 3 \mathrm{HT}-5 \mathrm{~F})_{0.3}-\left(\mathrm{P} 3 \mathrm{HT}-5 \mathrm{~F}-\mathrm{N}-\mathrm{C}_{70}\right)_{0.1}\right]$, respectively. The inset in (a) shows the Normalized Absorption spectra of $\mathrm{C}_{60}$ and $\mathrm{C}_{70}$ in o-DCB solutions. 
The PL spectra of side- $\left[\mathrm{P}_{3} \mathrm{HT}_{0.6}-(\mathrm{P} 3 \mathrm{HT}-5 \mathrm{~F})_{0.4}\right]$ and its respective hybrids with $\mathrm{C}_{60}$ and $\mathrm{C}_{70}$ both in $o$-DCB solutions and in film form are shown in Figure 9. The $o$-DCB solutions of the hybrid materials, upon excitation at $470 \mathrm{~nm}$, presented blue shifted spectra and broader photoluminescence curves in the region 500-650 nm, compared to the un-functionalized P3HT (Figure 9a). In film form, after excitation at the UV-Vis films maxima, the PL spectra followed the trend of the respective solutions also showing a blue shift compared to the neat $r$-P3HT. A small quenching of the hybrids' photoluminescence intensity in film form was observed, $\left[\mathrm{P}_{3} \mathrm{HT}_{0.6}-(\mathrm{P} 3 \mathrm{HT}-5 \mathrm{~F})_{0.2}-\left(\mathrm{P} 3 \mathrm{HT}-5 \mathrm{~F}-\mathrm{N}-\mathrm{C}_{60}\right)_{0.2}\right]$ green-colored line and $\left[\mathrm{P}_{3} \mathrm{HT}_{0.6}-(\mathrm{P} 3 \mathrm{HT}-5 \mathrm{~F})_{0.3}-\left(\mathrm{P} 3 \mathrm{HT}-5 \mathrm{~F}-\mathrm{N}-\mathrm{C}_{70}\right)_{0.1}\right]$ blue-colored line of Figure 9b, that is attributed to the electron accepting fullerene parts interacting electronically with the electron donating P3HT polymeric backbone and the perturbation of the P3HT's backbone due to the side functionalization.
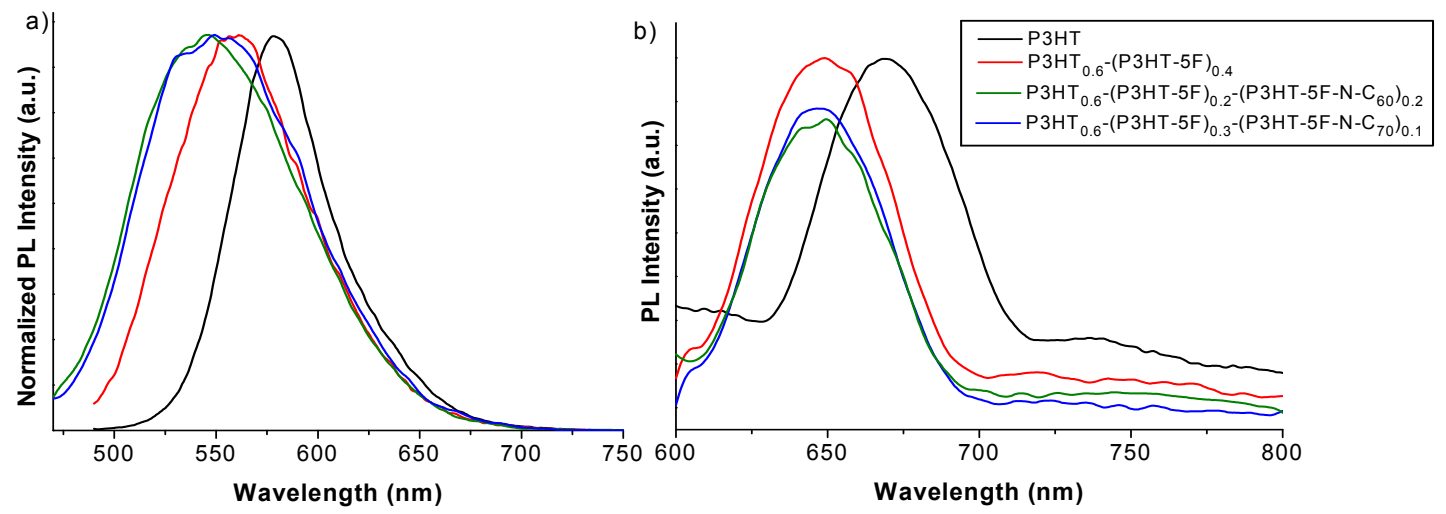

Figure 9. Photoluminescence spectra of: (a) $o$-DCB solutions; and (b) in film form of un functionalized $r r-\mathrm{P} 3 \mathrm{HT}$, side functionalized [P3HT $\left.0.6-(\mathrm{P} 3 \mathrm{HT}-5 \mathrm{~F})_{0.4}\right],\left[\mathrm{P}_{3} \mathrm{HT}_{0.6}-(\mathrm{P} 3 \mathrm{HT}-5 \mathrm{~F})_{0.2}-\left(\mathrm{P} 3 \mathrm{HT}-5 \mathrm{~F}-\mathrm{N}-\mathrm{C}_{60}\right)_{0.2}\right]$ hybrid and $\left[\mathrm{P}_{3} \mathrm{HT}_{0.6}-(\mathrm{P} 3 \mathrm{HT}-5 \mathrm{~F})_{0.3}-\left(\mathrm{P} 3 \mathrm{HT}-5 \mathrm{~F}-\mathrm{N}-\mathrm{C}_{70}\right)_{0.1}\right]$ hybrid, respectively.

\subsection{Morphology Characterization}

Thin film morphology of side perfluorophenyl functionalized $\left[\mathrm{P}_{3} \mathrm{HT}_{0.6}-(\mathrm{P} 3 \mathrm{HT}-5 \mathrm{~F})_{0.4}\right]$ and its respective hybrids with $\mathrm{C}_{60}$ and $\mathrm{C}_{70}$ was investigated using transmission electron spectroscopy (TEM) (Figure 10). The initial side $\left[\mathrm{P}_{3} \mathrm{HT}_{0.6}-(\mathrm{P} 3 \mathrm{HT}-5 \mathrm{~F})_{0.4}\right]$ formed a uniform thin film in the nanometer scale. The corresponding $\mathrm{C}_{60}$ based hybrid, $\left[\mathrm{P}_{3} \mathrm{HT}_{0.6}-(\mathrm{P} 3 \mathrm{HT}-5 \mathrm{~F})_{0.2}-\left(\mathrm{P} 3 \mathrm{HT}-5 \mathrm{~F}-\mathrm{N}-\mathrm{C}_{60}\right)_{0.2}\right]$, formed films with large domains compared to the initial perfluorophenyl modified $\mathrm{P} 3 \mathrm{HT}$, with darker and brighter regions. In contrast, the $\mathrm{C}_{70}$ based hybrid polymer, $\left[\mathrm{P}_{3} \mathrm{HT}_{0.6}-(\mathrm{P} 3 \mathrm{HT}-5 \mathrm{~F})_{0.3}-\left(\mathrm{P} 3 \mathrm{HT}-5 \mathrm{~F}-\mathrm{N}-\mathrm{C}_{70}\right)_{0.1}\right]$, presented a uniform nanophase separated thin film formation with well resolved small domains in analogy to its non hybrid initial polymer, $\left[\mathrm{P}^{3} \mathrm{HT}_{0.6}-(\mathrm{P} 3 \mathrm{HT}-5 \mathrm{~F})_{0.4}\right]$.
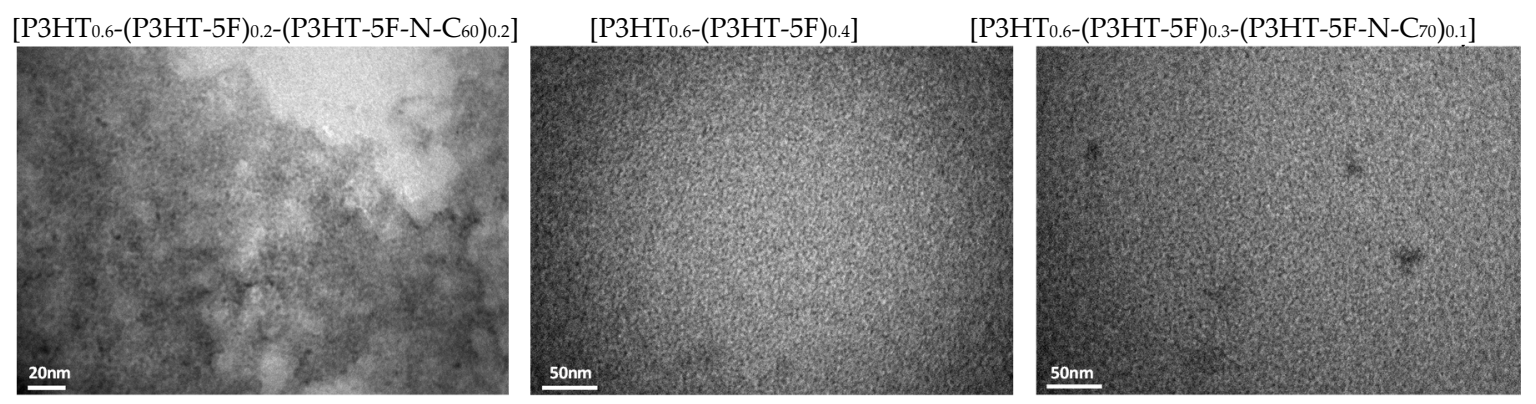

Figure 10. TEM images of the initial $\left[\mathrm{P}_{3} \mathrm{HT}_{0.6}-(\mathrm{P} 3 \mathrm{HT}-5 \mathrm{~F})_{0.4}\right]$ and its respective hybrids $\left[\mathrm{P} \mathrm{HT}_{0.6}-(\mathrm{P} 3 \mathrm{HT}-5 \mathrm{~F})_{0.2}-\left(\mathrm{P} 3 \mathrm{HT}-5 \mathrm{~F}-\mathrm{N}-\mathrm{C}_{60}\right)_{0.2}\right]$ and $\left[\mathrm{P}_{3} \mathrm{HT}_{0.6}-(\mathrm{P} 3 \mathrm{HT}-5 \mathrm{~F})_{0.3}-\left(\mathrm{P} 3 \mathrm{HT}-5 \mathrm{~F}-\mathrm{N}-\mathrm{C}_{70}\right)_{0.1}\right]$ without thermal annealing. 
Moreover, a typical $\mathrm{P} 3 \mathrm{HT}: \mathrm{PC}_{70} \mathrm{BM}$ blend of 1:1 $w / w$ ratio was employed to prepare two new blends with the $\left[\mathrm{P}_{3} \mathrm{HT}_{0.6}-(\mathrm{P} 3 \mathrm{HT}-5 \mathrm{~F})_{0.3}-\left(\mathrm{P} 3 \mathrm{HT}-5 \mathrm{~F}-\mathrm{N}-\mathrm{C}_{70}\right)_{0.1}\right]$ hybrid polymer. The hybrid material was added at a $20 \mathrm{wt} \%$ and at a $50 \mathrm{wt} \%$ percent, respectively, over the total weight of the P3HT:PC $70 \mathrm{BM}$ initial blend. The effect of the additive on the morphology of the initial blend was investigated via TEM microscopy. Figure 11 presents the respective TEM images in $100 \mathrm{~nm}$ and in $20 \mathrm{~nm}$ scale, of the initial blend and of the blends containing the hybrid polymer without any thermal or other solvent vapor treatment. The $\mathrm{P} 3 \mathrm{HT}: \mathrm{PC}_{70} \mathrm{BM}$ blend presented uniform thin film with nanophase separation. The morphology of the blend containing $20 \%$ of the side $C_{70}$ based hybrid polymer did not present any differentiations, even at the $20 \mathrm{~nm}$ scale, showing the probable stabilization of the initial blends morphology. On the other hand, the blend with the $50 \%$ of the side $C_{70}$ hybrid polymer formed more heterogeneous films in which darker domains are present.

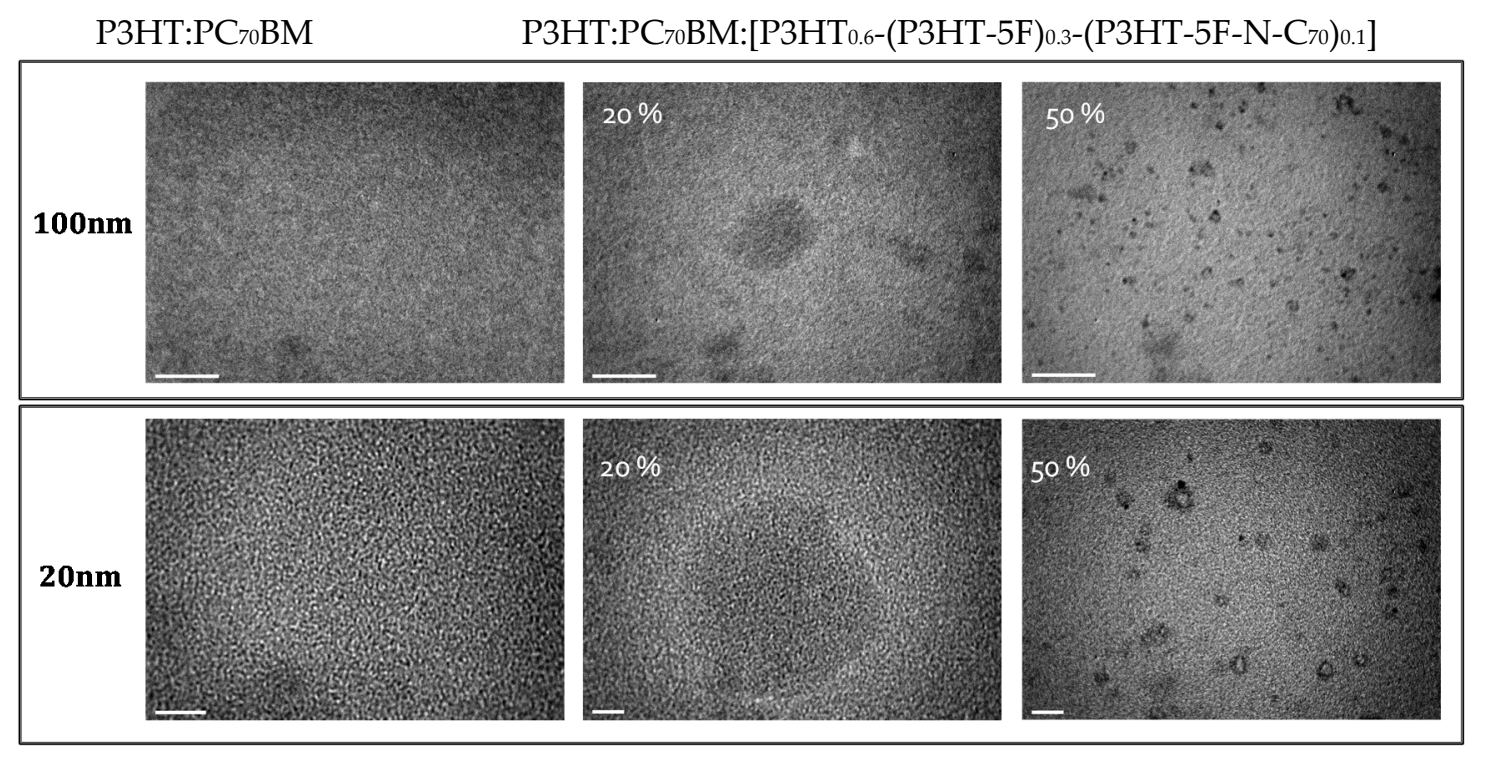

Figure 11. TEM images of a $\mathrm{P} 3 \mathrm{HT}: \mathrm{PC}_{70} \mathrm{BM} \quad 1: 1 w / w$ blend and of $\mathrm{P} 3 \mathrm{HT}: \mathrm{PC}_{70} \mathrm{BM}$ : $\left[\mathrm{P}_{3} \mathrm{HT}_{0.6}-(\mathrm{P} 3 \mathrm{HT}-5 \mathrm{~F})_{0.3}-\left(\mathrm{P} 3 \mathrm{HT}-5 \mathrm{~F}-\mathrm{N}-\mathrm{C}_{70}\right)_{0.1}\right]$ blends with a $20 \mathrm{wt} \%$ and a $50 \mathrm{wt} \%$ of the $\left[\mathrm{P}_{3} \mathrm{HT}_{0.6}-(\mathrm{P} 3 \mathrm{HT}-5 \mathrm{~F})_{0.3}-\left(\mathrm{P} 3 \mathrm{HT}-5 \mathrm{~F}-\mathrm{N}-\mathrm{C}_{70}\right)_{0.1}\right]$ hybrid, respectively. For the top images, the scale bars correspond to $100 \mathrm{~nm}$ while, for the bottom images, they correspond to $20 \mathrm{~nm}$.

\section{Conclusions}

In this work, modification in various ratios of the $r r$-P3HT backbone in order to introduce the perfluorophenyl functionality at the 4-position of the thiophene unit has been efficiently performed. Thereafter, and based on our previous reported methodology, the perfluorophenyl moieties transformed into azides, from which hybrid materials with fullerenes, $C_{60}$ or $C_{70}$, have been synthesized aiming to develop efficient compatibilizers and stabilizers of P3HT:fullerene active layers typically employed in large area flexible OPVs. The side-functionalized P3HTs and their respective hybrid polymers have been characterized in respect to their optical and morphological properties. In solutions and in film form, all the side-functionalized materials presented blue shifted absorbance curves due to the perturbation of regioregularity of polythiophene. Regarding their photoluminescence in film form, the hybrid materials presented moderate photoluminescence quenching. The $\mathrm{C}_{70}$ based hybrid polymer formed uniform nanophase separated thin films while the $\mathrm{C}_{60}$ based hybrid formed more heterogeneous thin films exhibiting larger domains. In order to investigate their applicability as potential compatibilizers of polythiophene:fullerene BHJ active layers, selected hybrids were evaluated for their influence on the morphology of a typical $\mathrm{P} 3 \mathrm{HT}: \mathrm{PC}_{70} \mathrm{BM}$ active layer blend. More specifically, when the percentage of the hybrid was low compared to the total blend weight ratio, the morphology 
was not affected. However, when the hybrid polymer was added at a higher percentage, the final blend presented irregularities and large domains were created throughout the blend.

Based on these findings it can be concluded that the particular "perfluorophenyl"-"azide"-"carbon nanostructure hybrid" methodology is conveniently applicable for the development of side hybrid semiconducting polymer electron donors allowing the insertion of fullerene species in the desired percentage. Such hybrid polymer-fullerene materials can be employed as additives of typical polymer-donor:fullerene-acceptor active layer blends for OPVs.

Acknowledgments: The authors thank Mr. Dimitris Vachliotis of the Instrumental Analysis Laboratory, University of Patras for his efforts during the NMR experiments and Maria Kollia from the Laboratory of Electron Microscopy and Microanalysis at the University of Patras for the TEM images. This research has been financed by the "ARISTEIA" Action of the "Operational Programme Education and Lifelong Learning" co-funded by the European Social Fund (ESF) and National Resources) through the project "Design and Development of New Electron Acceptor Polymeric and Hybrid Materials and their Application in Organic Photovoltaics"_-DENEA 2780.

Author Contributions: Sofia Kakogianni performed the experiments, analyzed data and wrote parts of the manuscript. Aikaterini K. Andreopoulou and Joannis K. Kallitsis supervised the work and wrote parts of the manuscript.

Conflicts of Interest: The authors declare no conflict of interest.

\section{References}

1. Yu, J.; Zheng, Y.; Huang, J. Towards high performance organic photovoltaic cells: A review of recent development in organic photovoltaics. Polymers 2014, 6, 2473-2509. [CrossRef]

2. Mazzio, K.A.; Luscombe, C.K. The future of organic photovoltaics. Chem. Soc. Rev. 2015, 44, 78-90. [CrossRef] [PubMed]

3. Lu, L.; Zheng, T.; Wu, Q.; Schneider, A.M.; Zhao, D.; Yu, L. Recent advances in bulk heterojunction polymer solar cells. Chem. Rev. 2015, 115, 12666-12731. [CrossRef] [PubMed]

4. Ma, W.; Yang, C.; Gong, X.; Lee, K.; Heeger, A.J. Thermally stable, efficient polymer solar cells with nanoscale control of the interpenetrating network morphology. Adv. Funct. Mater. 2005, 15, 1617-1622. [CrossRef]

5. Choulis, S.A.; Kim, Y.; Nelson, J.; Bradley, D.D.C.; Giles, M.; Shkunov, M.; McCulloch, I. High ambipolar and balanced carrier mobility in regioregular poly(3-hexylthiophene). Appl. Phys. Lett. 2004, 85, 3890-3892. [CrossRef]

6. Schafferhans, J.; Baumann, A.; Wagenpfahl, A.; Deibel, C.; Dyakonov, V. Oxygen doping of P3HT:PCBM blends: Influence on trap states, charge carrier mobility and solar cell performance. Org. Electron. 2010, 11, 1693-1700. [CrossRef]

7. Dang, M.T.; Wantz, G.; Bejbouji, H.; Urien, M.; Dautel, O.J.; Vignau, L.; Hirsch, L. Polymeric solar cells based on P3HT:PCBM: Role of the casting solvent. Sol. Energy Mater. Sol. Cells 2011, 95, 3408-3418. [CrossRef]

8. Baek, W.-H.; Yang, H.; Yoon, T.-S.; Kang, C.J.; Lee, H.H.; Kim, Y.-S. Effect of P3HT:PCBM concentration in solvent on performances of organic solar cells. Sol. Energy Mater. Sol. Cells 2009, 93, 1263-1267. [CrossRef]

9. Carlé, J.E.; Krebs, F.C. Technological status of organic photovoltaics (OPV). Sol. Energy Mater. Sol. Cells 2013, 119, 309-310. [CrossRef]

10. Kapnopoulos, C.; Mekeridis, E.D.; Tzounis, L.; Polyzoidis, C.; Zachariadis, A.; Tsimikli, S.; Gravalidis, C.; Laskarakis, A.; Vouroutzis, N.; Logothetidis, S. Fully gravure printed organic photovoltaic modules: A straightforward process with a high potential for large scale production. Sol. Energy Mater. Sol. Cells 2016, 144, 724-731. [CrossRef]

11. Kallitsis, J.K.; Kourkouli, S.; Andreopoulou, A.K. Organic Polymeric Semiconductor Materials for Applications in Photovoltaic Cells Part 1: Properties and Materials, Handbook on Flexible Organic Electronics: Materials, Manufacturing and Applications; Logothetidis, S., Ed.; Woodhead Publishing Limited: Cambridge, UK, 2015; pp. 85-114.

12. Scharber, M.C.; Mühlbacher, D.; Koppe, M.; Denk, P.; Waldauf, C.; Heeger, A.J.; Brabec, C.J. design rules for donors in bulk-heterojunction solar cells-Towards $10 \%$ energy-conversion efficiency. Adv. Mater. 2006, 18, 789-794. [CrossRef]

13. Liu, X.; Chen, H.; Tan, S. Overview of high-efficiency organic photovoltaic materials and devices. Renew. Sustain. Energy Rev. 2015, 52, 1527-1538. [CrossRef] 
14. Gao, M.; Subbiah, J.; Geraghty, P.B.; Chen, M.; Purushothaman, B.; Chen, X.; Qin, T.; Vak, D.; Scholes, F.H.; Watkins, S.E.; et al. Development of a high-performance donor-acceptor conjugated polymer: Synergy in materials and device optimization. Chem. Mater. 2016, 28, 3481-3487. [CrossRef]

15. Chen, J.; Cao, Y. Development of novel conjugated donor polymers for high efficiency bulkheterojunction photovoltaic devices. Acc. Chem. Res. 2009, 42, 1709-1718. [CrossRef] [PubMed]

16. He, Y.; Li, Y. Fullerene derivative acceptors for high performance polymer solar cells. Phys. Chem. Chem. Phys. 2011, 13, 1970-1983. [CrossRef] [PubMed]

17. He, Y.; Chen, H.-Y.; Hou, J.; Li, Y. Indene-C60 bisadduct: A new acceptor for high-performance polymer solar cells. J. Am. Chem. Soc. 2010, 132, 1377-1382. [CrossRef] [PubMed]

18. He, Y.; Zhao, G.; Peng, B.; Li, Y. High-yield synthesis and electrochemical and photovoltaic properties of indene-C70 bisadduct. Adv. Funct. Mater. 2010, 20, 3383-3389. [CrossRef]

19. Facchetti, A. Polymer donor-polymer acceptor (all-polymer) solar cells. Mater. Today 2013, 16, $123-132$. [CrossRef]

20. Bin, H.; Zhang, Z.-G.; Gao, L.; Chen, S.; Zhong, L.; Xue, L.; Yang, C.; Li, Y. Non-fullerene polymer solar cells based on alkylthio and fluorine substituted 2D-conjugated polymers reach 9.5\% efficiency. J. Am. Chem. Soc. 2016, 138, 4657-4664. [CrossRef] [PubMed]

21. Kim, Y.; Lim, E. Development of polymer acceptors for organic photovoltaic cells. Polymers 2014, 6, 382-407. [CrossRef]

22. Brady, M.A.; Su, G.M.; Chabinyc, M.L. Recent progress in the morphology of bulk heterojunction photovoltaics. Soft Matter 2011, 7, 11065-11077. [CrossRef]

23. Ruderer, M.A.; Muller-Buschbaum, P. Morphology of polymer-based bulk heterojunction films for organic photovoltaics. Soft Matter 2011, 7, 5482-5493. [CrossRef]

24. Zhao, Y.; Xie, Z.; Qu, Y.; Geng, Y.; Wang, L. Solvent-vapor treatment induced performance enhancement of poly(3-hexylthiophene): Methanofullerene bulk-heterojunction photovoltaic cells. Appl. Phys. Lett. 2007, 90, 043504. [CrossRef]

25. Moulé, A.J.; Meerholz, K. Controlling morphology in polymer-fullerene mixtures. Adv. Mater. 2008, 20, 240-245. [CrossRef]

26. Yao, Y.; Hou, J.; Xu, Z.; Li, G.; Yang, Y. Effects of solvent mixtures on the nanoscale phase separation in polymer solar cells. Adv. Funct. Mater. 2008, 18, 1783-1789. [CrossRef]

27. Angiolini, L.; Cocchi, V.; Lanzi, M.; Salatelli, E.; Tonelli, D.; Vlamidis, Y. Novel regioregular polythiophenes containing side-chain porphyrin groups for polymeric photovoltaic cells. Mat. Chem. Phys. 2014, 146, 464-471. [CrossRef]

28. Bertho, S.; Campo, B.; Piersimoni, F.; Spoltore, D.; D’Haen, J.; Lutsen, L.; Maes, W.; Vanderzande, D.; Manca, J. Improved thermal stability of bulk heterojunctions based on side-chain functionalized poly(3-alkylthiophene) copolymers and PCBM. Sol. Energy Mater. Sol. Cells 2013, 110, 69-76. [CrossRef]

29. Jaymand, M.; Hatamzadeh, M.; Omidi, Y. Modification of polythiophene by the incorporation of processable polymeric chains: Recent progress in synthesis and applications. Prog. Polym. Sci. 2015, 47, 26-69. [CrossRef]

30. Lobez, J.M.; Andrew, T.L.; Bulović, V.; Swager, T.M. Improving the performance of P3HT-fullerene solar cells with side chain functionalized poly(thiophene) additives: A new paradigm for polymer design. ACS Nano 2012, 6, 3044-3056. [CrossRef] [PubMed]

31. Wang, H.-J.; Chen, C.-P.; Jeng, R.-J. Polythiophenes comprising conjugated pendants for polymer solar cells: A review. Materials 2014, 7, 2411-2439. [CrossRef]

32. Valderrama-García, B.X.; Rodríguez-Alba, E.; Morales-Espinoza, E.G.; Moineau Chane-Ching, K.; Rivera, E. Synthesis and characterization of novel polythiophenes containing pyrene chromophores: Thermal, optical and electrochemical properties. Molecules 2016, 21, 172. [CrossRef] [PubMed]

33. Liu, J.; Zhu, X.; Li, J.; Shen, J.; Tu, G. Enhancing the thermal stability of the bulk-heterojunction photovoltaics based on P3HT/PCBM by incorporating diblock amphipathic P3HT-PEO at D/A interface. RSC Adv. 2016, 6, 61934-61943. [CrossRef]

34. Rumer, J.W.; McCulloch, I. Organic photovoltaics: Crosslinking for optimal morphology and stability. Mater. Today 2015, 18, 425-435. [CrossRef]

35. Wantz, G.; Derue, L.; Dautel, O.; Rivaton, A.; Hudhomme, P.; Dagron-Lartigau, C. Stabilizing polymer-based bulk heterojunction solar cells via crosslinking. Polym. Int. 2014, 63, 1346-1361. [CrossRef] 
36. Li, F.; Yager, K.G.; Dawson, N.M.; Jiang, Y.-B.; Malloy, K.J.; Qin, Y. Nano-structuring polymer/fullerene composites through the interplay of conjugated polymer crystallization, block copolymer self-assembly and complementary hydrogen bonding interactions. Polym. Chem. 2015, 6, 721-731. [CrossRef]

37. Huang, P.-T.; Chen, Y.-H.; Lin, B.-Y.; Chuang, W.-P. Homogenized poly(3-hexylthiophene)/methanofullerene film by addition of end-functionalized compatibilizer and its application to polymer solar cells. Int. J. Photoenergy 2015, 2015, 762532. [CrossRef]

38. Kim, H.J.; Han, A.-R.; Cho, C.-H.; Kang, H.; Cho, H.-H.; Lee, M.Y.; Fréchet, J.M.J.; Oh, J.H.; Kim, B.J. Solvent-resistant organic transistors and thermally stable organic photovoltaics based on cross-linkable conjugated polymers. Chem. Mater. 2012, 24, 215-221. [CrossRef]

39. Yuan, K.; Chen, L.; Chen, Y. Nanostructuring compatibilizers of block copolymers for organic photovoltaics. Polym. Int. 2014, 63, 593-606. [CrossRef]

40. Kallitsis, J.K.; Anastasopoulos, C.; Andreopoulou, A.K. Functional semiconductors targeting copolymer architectures and hybrid nanostructures. MRS Commun. 2015, 5, 365-382. [CrossRef]

41. Li, M.; Xu, P.; Yang, J.; Yang, S. Donor-p-acceptor double-cable polythiophenes bearing fullerene pendant with tunable donor/acceptor ratio: A facile postpolymerization. J. Mater. Chem. 2010, 20, 3953-3960. [CrossRef]

42. Gholamkhass, B.; Peckham, T.J.; Holdcroft, S. Poly(3-hexylthiophene) bearing pendant fullerenes: Aggregation vs. self-organization. Polym. Chem. 2010, 1, 708-719. [CrossRef]

43. Lanzi, M.; Salatelli, E.; Benelli, T.; Caretti, D.; Giorgini, L.; Di-Nicola, F.P. A regioregular polythiophene-fullerene for polymeric solar cells. J. Appl. Polym. Sci. 2015, 132. [CrossRef]

44. Hufnagel, M.; Fischer, M.; Thurn-Albrecht, T.; Thelakkat, M. Influence of fullerene grafting density on structure, dynamics, and charge transport in P3HT-b-PPC61BM block copolymers. Macromolecules 2016, 49, 1637-1647. [CrossRef]

45. Raïssi, M.; Erothu, H.; Ibarboure, E.; Cramail, H.; Vignau, L.; Cloutet, E.; Hiorns, R.C. Fullerene-capped copolymers for bulk heterojunctions: Device stability and efficiency improvements. J. Mater. Chem. A 2015, 3, 18207-18221. [CrossRef]

46. Kourkouli, S.N.; Siokou, A.; Stefopoulos, A.A.; Ravani, F.; Plocke, T.; Müller, M.; Maultzsch, J.; Thomsen, C.; Papagelis, K.; Kallitsis, J.K. Electronic properties of semiconducting polymer-functionalized single wall carbon nanotubes. Macromolecules 2013, 46, 2590-2598. [CrossRef]

47. Stefopoulos, A.A.; Chochos, C.L.; Prato, M.; Pistolis, G.; Papagelis, K.; Petraki, F.; Kennou, S.; Kallitsis, J.K. Novel hybrid materials consisting of regioregular poly(3-octylthiophene)s covalently attached to single wall carbon nanotubes. Chem. Eur. J. 2008, 14, 8715-8724. [CrossRef] [PubMed]

48. Stefopoulos, A.A.; Kourkouli, S.N.; Economopoulos, S.; Ravani, F.; Andreopoulou, A.; Papagelis, K.; Siokou, A.; Kallitsis, J.K. Polymer and hybrid electron accepting materials based on a semiconducting perfluorophenylquinoline. Macromolecules 2010, 43, 4827-4828. [CrossRef]

49. Kakogianni, S.; Kourkouli, S.N.; Andreopoulou, A.K.; Kallitsis, J.K. A versatile approach for creating hybrid semiconducting polymer-fullerene architectures for organic electronics. J. Mater. Chem. A 2014, 2, 8110-8117. [CrossRef]

50. Sygellou, L.; Kakogianni, S.; Andreopoulou, A.K.; Theodosiou, K.; Leftheriotis, G.; Kallitsis, J.K.; Siokou, A. Evaluation of the electronic properties of perfluorophenyl functionalized quinolines and their hybrids with carbon nanostructures. Phys. Chem. Chem. Phys. 2016, 18, 4154-4165. [CrossRef] [PubMed]

51. Raja, R.; Liu, W.-S.; Hsiow, C.-Y.; Rwei, S.-P.; Chiu, W.-Y.; Wang, L. Terthiophene-C60 dyad as donor/acceptor compatibilizer for developing highly stable P3HT/PCBM bulk heterojunction solar cells. J. Mater. Chem. A 2015, 3, 14401-14408. [CrossRef]

52. Perrin, L.; Legros, M.; Mercier, R. Design of a series of polythiophenes containing C60 groups: Synthesis and optical and electrochemical properties. Macromolecules 2015, 48, 323-336. [CrossRef]

53. Yameen, B.; Puerckhauer, T.; Ludwig, J.; Ahmed, I.; Altintas, O.; Fruk, L.; Colsmann, A.; Barner-Kowollik, C. $\pi$-conjugated polymer-fullerene covalent hybrids via ambient conditions diels-alder ligation. Small 2014, 10, 3091-3098. [CrossRef] [PubMed]

54. Kakogianni, S.; Lebedeva, M.A.; Paloumbis, G.; Andreopoulou, A.K.; Porfyrakis, K.; Kallitsis, J.K. Semiconducting end-perfluorinated P3HT-fullerenic hybrids as potential additives for $\mathrm{P} 3 \mathrm{HT} / \mathrm{IC}_{70} \mathrm{BA}$ blends. RSC Adv. 2016, 6, 98306-98316. [CrossRef] 
55. Loewe, R.S.; Ewbank, P.C.; Liu, J.; Zhai, L.; McCullough, R.D. Regioregular, head-to-tail coupled poly(3-alkylthiophenes) made easy by the GRIM method: Investigation of the reaction and the origin of regioselectivity. Macromolecules 2001, 34, 4324-4333. [CrossRef]

56. Chochos, C.L.; Economopoulos, S.P.; Deimede, V.; Gregoriou, V.G.; Lloyd, M.T.; Malliaras, G.G.; Kallitsis, J.K. Synthesis of a soluble n-type cyano substituted polythiophene derivative: A potential electron acceptor in polymeric solar cells. J. Phys. Chem. C 2007, 111, 10732-10740. [CrossRef]

57. Economopoulos, S.P.; Chochos, C.L.; Gregoriou, V.G.; Kallitsis, J.K.; Barrau, S.; Hadziioannou, G. Novel brush-type copolymers bearing thiophene backbone and side chain quinoline blocks. Synthesis and their use as a compatibilizer in thiophene-quinoline polymer blends. Macromolecules 2007, 40, 921-927. [CrossRef]

58. Li, Y.N.; Vamvounis, G.; Holdcroft, S. Facile functionalization of poly(3-alkylthiophene)s via electrophilic substitution. Macromolecules 2001, 34, 141-143. [CrossRef]

59. Li, Y.N.; Vamvounis, G.; Yu, J.; Holdcroft, S. A novel and versatile methodology for functionalization of conjugated polymers. Transformation of poly(3-bromo-4-hexylthiophene) via palladium-catalyzed coupling chemistry. Macromolecules 2001, 34, 3130-3132. [CrossRef]

(C) 2016 by the authors; licensee MDPI, Basel, Switzerland. This article is an open access article distributed under the terms and conditions of the Creative Commons Attribution (CC-BY) license (http://creativecommons.org/licenses/by/4.0/). 